\title{
A Spatial Analysis of Gaziantep Railway and Its Station Throughout History
}

\author{
Hilal Aycl1, Derya Güleç Özer²*, Abdulkadir Güleç3 \\ 1 Department of Architecture, Faculty of Architecture, Gazi University, 06570 Ankara, 5 Yükseliş Street, Turkey \\ 2 Department of Architecture, Faculty of Architecture, Istanbul Technical University, 34367 Şişli, Istanbul, 2 Taşkışla Road, Turkey \\ 3 Department of Construction, Technical Sciences Vocational School, Sütçü İmam University, 46050 Onikişubat, Kahramanmaraş, \\ 251/A Batı Çevreyolu Boulevard, Turkey \\ *Corresponding author, e-mail: dgulec@itu.edu.tr
}

Received: 24 February 2020, Accepted: 03 August 2020, Published online: 07 September 2020

\begin{abstract}
The invention and proliferation of railways around the world emerged from the need for transport networks that would facilitate the movement of industrial goods produced during the Industrial Revolution. They were introduced to the Anatolian region in the lateOttoman period and gained importance as an indispensable part of the internal market in a new nation-state, the Republic of Turkey. Thanks to its location on the Silk Road, Gaziantep city in the southeastern part of Turkey, has always been a particularly important node on commercial routes. The present study describes the introduction of railways to Gaziantep province and the effects of Gaziantep Railway Station on the city at an urban and structural scale.

Although the first city plan was the Barsumyan-Nazaryan Plan (1920s), the railway system was introduced as a design object to Gaziantep City in the Jansen Plan (1938) and followed by the Aru-Söylemezoğlu Plan (1950), Gaziantep Plan (1973), and Oğuz Aldan Plan (1990). It can be concluded that its late introduction to Gaziantep delayed its integration with the transportation network covering other Anatolian cities at an urban and spatial level from an urban design perspective.
\end{abstract}

Keywords

Gaziantep railway, Gaziantep Railway Station, public space, Gaziantep City Plans

\section{Introduction}

The introduction of railways coincided with the invention of steam engines and railway systems as a solution to the problems encountered in the movement of raw industrial materials. Consequently, the history of railways dates to the Industrial Revolution, which changed the globe at a spatial level. It is not surprising that railways originated in the United Kingdom, given that it also initiated the Industrial Revolution. The first railway, which had a length of 10 miles, was built in Newcastle to move coal extracted from a mine using horses (Aydın, 2012). Given that 10 miles are approximately 16 kilometres, it is evident that the first railway construction attempt involved a relatively short distance (Slotterback, 2010). Although they were first designed as a tool to transport coal, railways quickly became national transportation used by many people in the UK from the 1820s (Aydin, 2012). Following their popularity in the UK, railway systems were introduced to many countries around the world, including the United States.
Meanwhile, in 1837, a chemist, Robert Davidson of Aberdeen, built the first known electric locomotive, which was powered by galvanic cells (batteries) (Day and McNeil, 1966). While railways facilitated life in Europe, they reshaped life in the United States (Aydın, 2012). In other words, railways functioned as the fundamental protector in a competitive capitalist environment (Aydın, 2012), and they rapidly gained popularity around the world.

The first attempt at railway construction and operation in Turkey was made by the British (Aydin, 2012). In the late-Ottoman period, a $211 \mathrm{~km}$ railway line was started between Alexandria and Cairo after the British obtained its franchise rights in 1851 (Gülsoy, 1994). Following this project, two new railway constructions, namely the Aydinİzmir railway line and the Tuna Black Sea railway line between Cernavodă and Constanta, started in the Anatolian region in 1856 and 1857, respectively (Aydın, 2012). A new railway line arriving in Ankara was also planned 
during the reign of Abdulhamid II and was completed in 1892 (Işıksaçan, 1961). Although Gaziantep was quite close to the Hejaz railway line that was designed during the second half of the nineteenth century, it was not one of the stations in the project. Consequently, Anatolia was significantly influenced by the railway system being introduced almost 30 years later than those in Europe. Similarly, it was only introduced to Gaziantep in 1953, even though it was a prominent location on the Silk Road.

Gaziantep is historically known for its production-oriented approach, and it was one of the most active trading centres on the Silk Road. However, the city was severely affected by World War I and found itself divided with Turks settled in the outskirts of the castle on the eastern side of the city, and non-Muslims, the majority of whom were Armenians, were settled on the western side (Cephanecigil, 2018). The Barsumyan-Nazaryan Plan that designed Gaziantep in the post-war period was prepared during the early-1920s (Fig. 1) (Cephanecigil, 2018). Even though the Barsumyan-Nazaryan Plan envisaged a city airport for the transportation network in Gaziantep, it must be noted that no railway lines were designed. The plan was prepared prior to the proclamation of the Republic as an administrative system; consequently, it took post-war conditions following World War I into account rather than the revolutionary decisions of the Republican era.
The new Turkish nation-state founded as a result of the Republican era took various spatial, economic, and social steps. One of the earliest steps of the new government was the planning of railway lines around the Anatolian region as a part of these policies. However, the policies of the early Republican era were based on the legacy of railway designs from the late-Ottoman period.

\section{Gaziantep Railway: The effect of the late introduction of railways as a design object on Gaziantep urban planning}

During the War of Independence, the Turks operated their railways through various organizations. However, a new operational organization was needed when the Anatolian railway lines were bought in the post-war period. Consequently, the Anatolian and Baghdad Railways and Directorate of Haydarpaşa Port and Waterfront were established on 22 April 1924 based on law 506 (Tekeli and İlkin, 2001). An educational institution was also founded to train railway specialists, and railway policy became national state policy in every possible way.

Initially, problems were encountered in the extraction of coal as a fuel for trains, and a low population exacerbated a lack of specialists. Under these conditions, Süleyman Sirrı Bey organized the First Railway Congress (Tekeli and İlkin, 2001). İlhan Tekeli and Selim İlkin

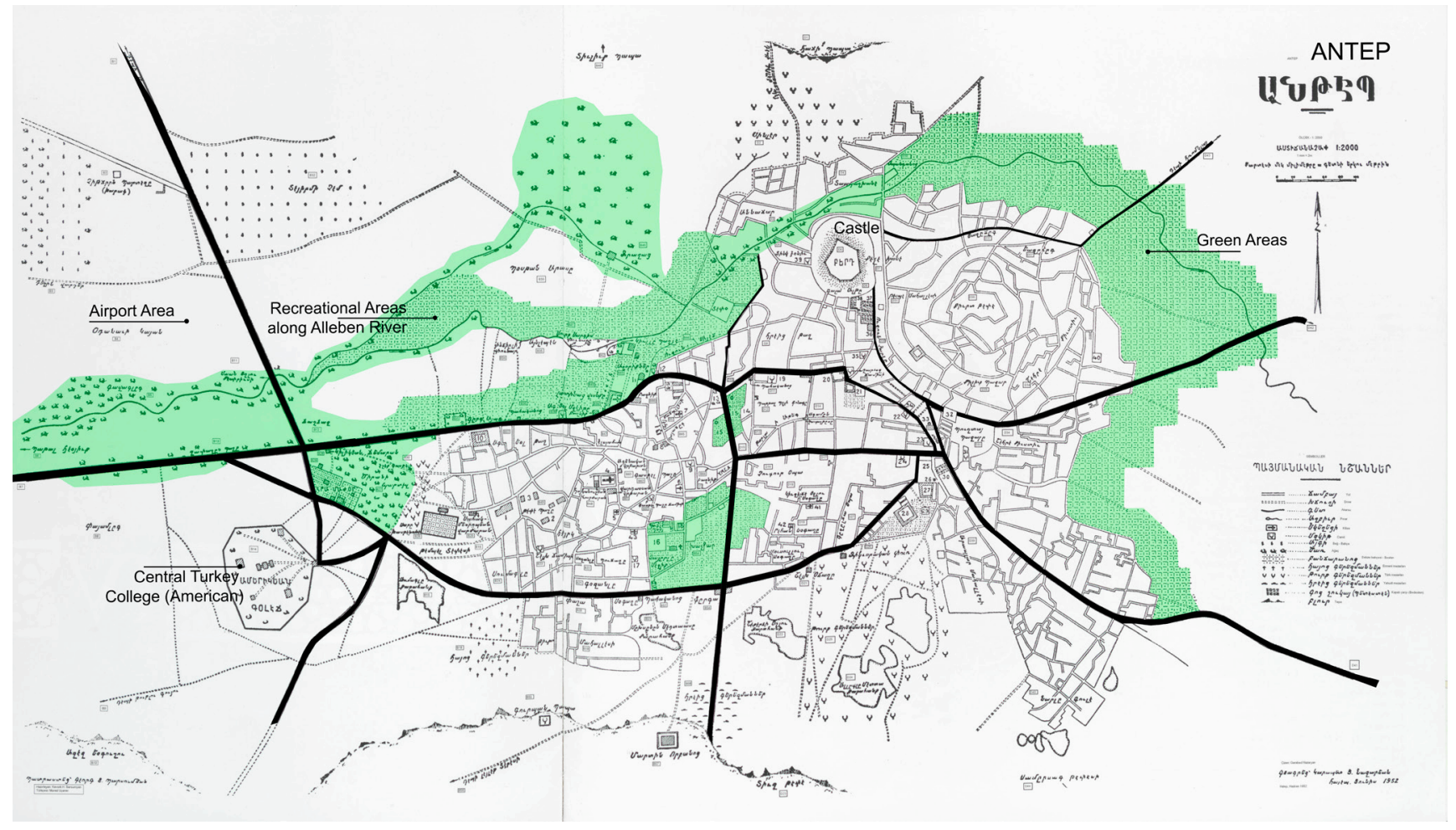

Fig. 1 Barsumyan-Nazaryan Plan of Gaziantep 
clearly stated that the reason why Anatolia, which was once part of the Ottoman Empire, was turned into a nation-state lies in the railway policies that were adopted in the early-Republican era. They also underline that studies and railway projects were inadequate in these years (Tekeli and İlkin, 2001).

The government also aimed to prevent foreign companies from operating railway lines during the War of Independence. After Ankara was selected as the capital city of the new Republic, a new railway line with its centre in Ankara was designed, and a closed system rail network was built in the early-Republican era instead of an open tree format network, which would have served the economic interests of the colonizing powers (Tekeli and İlkin, 2001). Thus, the government planned to control important production and commercial relations in the Anatolian region thanks to their control of the railway network. Despite various adverse conditions such as the Great Depression in 1929 or World War II, in the first quarter of the Republican era, it can be argued that the railway system preserved its position as a state policy.
Meanwhile, the rail networks were strengthened by the introduction of new lines, and their operation was handled by the government itself (Tekeli and İlkin, 2001). Given the importance attached to railways by nation-states during the war and post-war period, it is evident that they played a vital role in and offered great potential for urban planning.

Turkey inherited 3500 kilometres of railways from the Ottoman Empire in the early-Republican era (Aydın, 2012). Thus, railway projects were a priority for the Republic of Turkey, and new lines were added to the existing ones in this period. New railways were constructed one after another as a part of state policy, and they played an essential role in urban planning in the post-war period. Even in those days, the introduction of a railway line to a city was such an important event that a railway section was presented as a gift in the memory of the new railway station in Kayseri, opening on 29 May 1929 (Sönmez and Selçuk, 2018).

New spatial and economic decisions that were made as a part of nation-state policies in the early-Republican period influenced Gaziantep in various ways. However, the relationship between Gaziantep as a city and railway policy

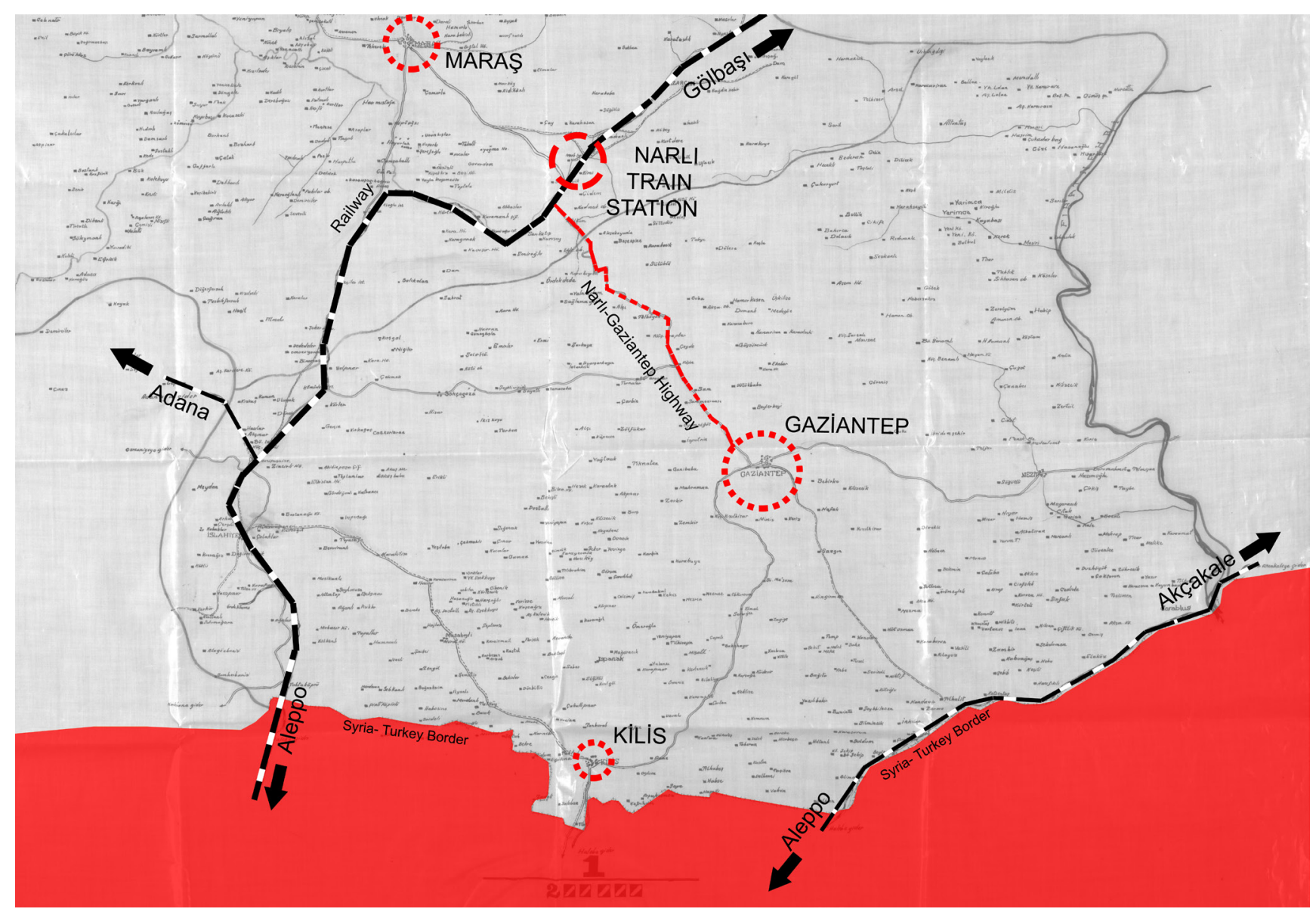

Fig. 2 Location of Gaziantep and its connection to Narlı Train Station (Gaziantep City Archive) 
did not develop in the same manner. Gaziantep was not included in the railway network construction plan covering railway networks within the boundaries of the Republic of Turkey in 1938. Although this network planned railway stations in Adana and Urfa city centre, the nearest railway station for Gaziantep was located in the Narlı district (Fig. 2). The lack of a railway station in Gaziantep can be attributed to this geographical region being surrounded by a relatively mountainous area. It should also be noted that a highway tunnel opening up the mountains in the region was only built in the 2000s. Therefore, structural and institutional railway systems were introduced to Adana much earlier than Gaziantep because the city was quite close to the ports and functioned as a bridge between Central and Southern Anatolia. Even today, Gaziantep railway is in the region that has Antep at its centre.

The need for a railway station in Gaziantep became more pressing during World War II as Abdurrahman Melek, a member of parliament from Gaziantep, clearly expressed this in his report sent to the Republican People's Party (CHP) headquarters. According to the article, the lack of a railway system in Gaziantep caused problems in providing even basic nutritional products, brought commercial activities to a halt, and made the supply of tyres and gas difficult. It was also stated in the report that Narlı Railway Station, which was the nearest railway station and 55 kilometres away from the city centre, did not suffice to meet the basic needs of the region (Kopar, 2011).
In a study of designed urban areas, factories and railway networks during the 1940s, H. Çăgatay Keskinok(2010) indicated that the nearest railway stations for Gaziantep were in Adana and Kahramanmaraş (Fig. 3). Thus, Gaziantep was not integrated into the Anatolian transportation network from a spatial point of view, which contradicted the spatial integrity of the transportation networks that was apparent in many Republican policies.

Eventually, a railway system was introduced to Gaziantep in 1953. However, many of the governments that came to power after 1950 either dismantled some railway lines or completely stopped operations (Aydın, 2012). The beginning of a relationship between Gaziantep and railway systems, thanks to the railway stations in Narl1Gaziantep and Nizip during the 1950s, indicates that the city developed differently from the railway-oriented state policies prior to the 1950s. Nevertheless, the urban design in Gaziantep was first shaped by the Gaziantep railway as a result of the 1938 Jansen Plan. Although the city was not included in the national railway network, the Jansen Plan, which was also prepared in 1938, involved the construction of a railway network as a location on the Silk Road, which was the first major railway location in Gaziantep's history (Çavdar, 2018). Although the national project that was aimed at existing railways and those under construction in 1938 did not include a railway station for Gaziantep's city centre, the Jansen Plan placed the city on the railway networks in the same period.

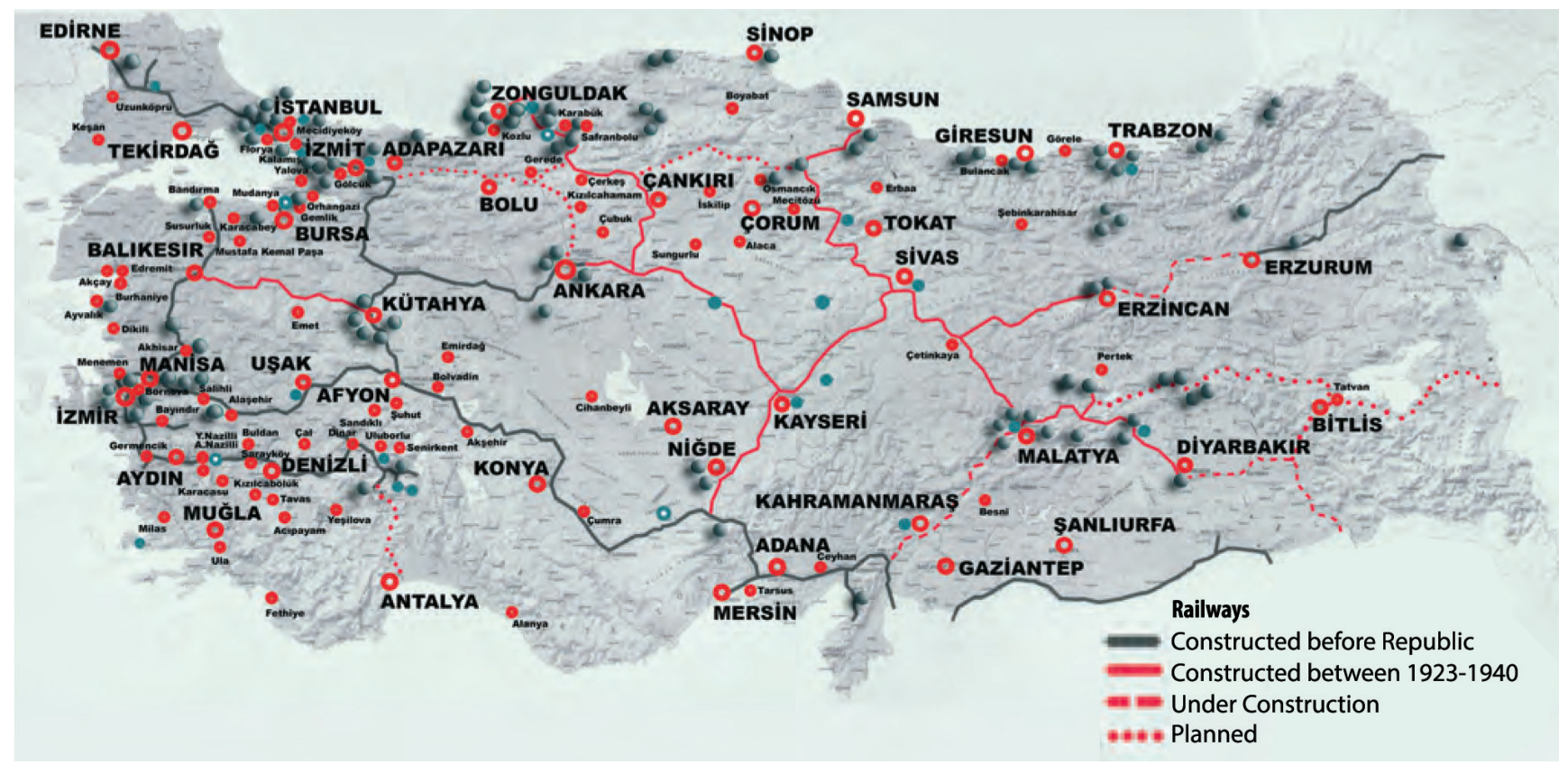

Fig. 3 Anatolian railway network system in 1940s and its relationship with industrial zones. (Keskinok, 2010). 
This contradiction can be explained in two ways: first, the Jansen Plan also aimed to design a railway-oriented network for other cities in Turkey (Ayc1 and Akbulut, 2018), and second, the Gaziantep Municipality demanded Jansen include the city in the related plan.

Jansen prepared an urban plan for Gaziantep in 1938 (Fig. 4). He also shared his views on Anatolian railway policies (Beyhan and Uğuz, 2012) in the navigation section of his reports where he underlined the need for aircraft as a transport mode between the Anatolian cities because of the mountainous Anatolian geography (Jansen, 1938). Jansen was later asked to design airports for each Anatolian city, which were included in his plans (Keskinok, 2018). For Gaziantep, Jansen planned industrial zones on important transportation arteries in the northern and eastern parts of the city such as Nizip and Halep Road, and designed accommodation areas for workers in these regions. The Jansen Plan for Gaziantep aimed to develop the western, northern and southern parts of the city. The northern part was planned as a 33ha industrial zone, which was to be integrated into a railway line. The railway station, located in the northern part of the city, was considered as a threshold for the urban transportation network (Yenice and Yenice, 2018).
Following the Jansen Plan prepared in 1938, a new urban plan was prepared by Kemal Ahmet Aru and Hamit Kemali Söylemezoğlu for Gaziantep in 1950. This plan situated Gaziantep Railway Station on the Karşıyaka settlement area to eliminate the need for accommodation in the city as a result of migration (Fig. 5). According to M. Serhat Yenice and Tülay Karadayı Yenice (2018), the major contribution of the 1950 plan to urban macroform Gaziantep was that the location of the railway network was moved towards a new centre in the northern part of the city, which combined the railway line with a travelling line known as the Silk Road today (Yenice and Yenice, 2018). It can be argued that the 1955 Plan had more influence on the location of this structure compared to the Jansen Plan.

The 1973 Gaziantep Plan designed the city as a centre for industrial activities (Yenice and Yenice, 2018). The plan was based on railway lines as a reference point to situate industrial zones. In 1990, the H. Oğuz Aldan Plan approached Gaziantep as a metropolitan city. However, the increasing number of industrial zones in Gaziantep weakened the relationship between its railways and its highways (Yenice and Yenice, 2018). Furthermore, highway-oriented transportation policies decreased the demand

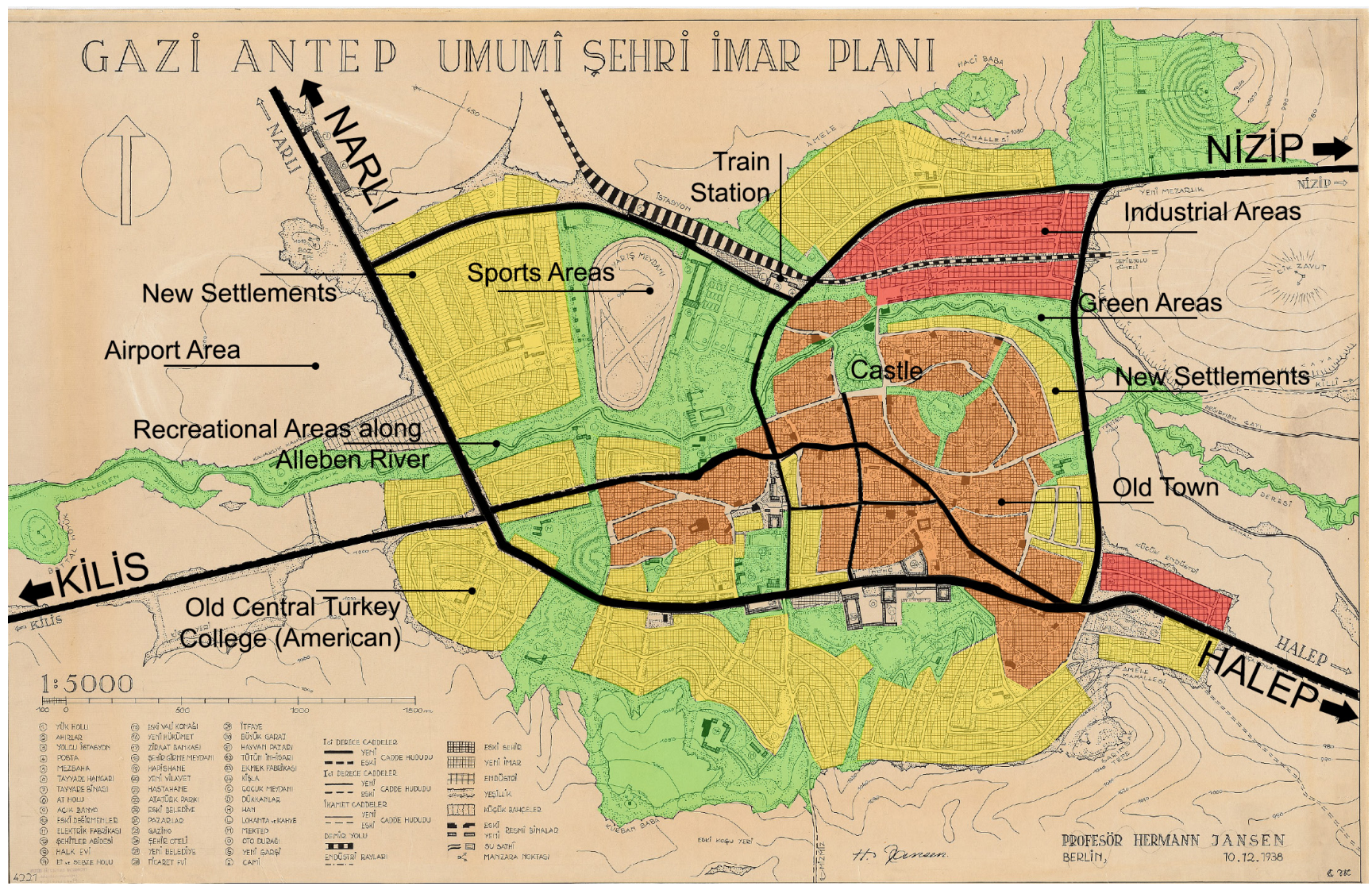

Fig. 4 Hermann Jansen-Walter Moest-Alfred Cuda 1938 Plan of Gaziantep, TU Berlin Architecture Museum, Archive no. 23414 (Jansen, 1938). 


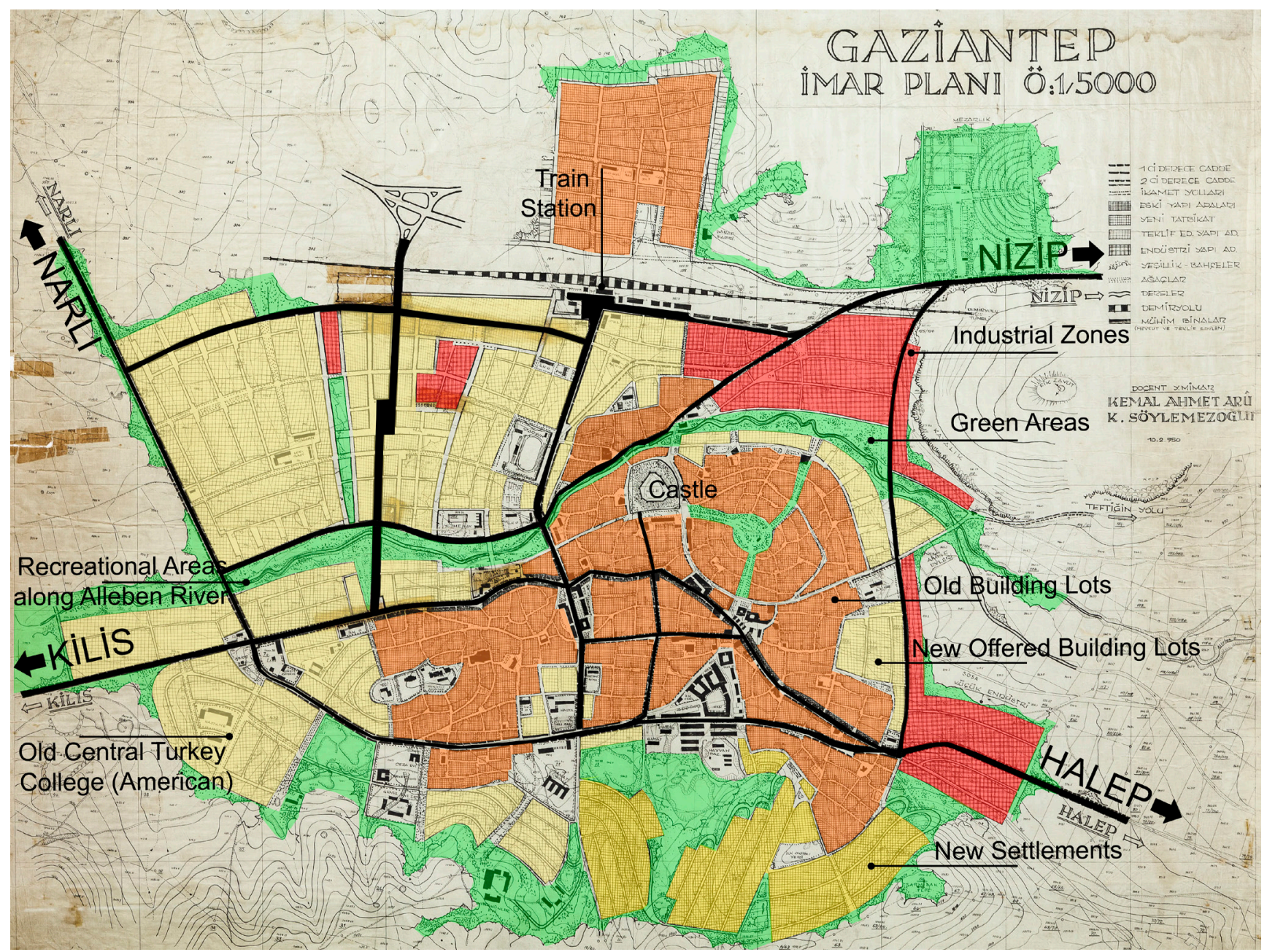

Fig. 51950 Plan of Gaziantep by Kemal Ahmet Aru and K. Söylemezoğlu, and it relationship with new development zones.

for railway lines around Turkey, including Gaziantep. Thus, the railway line in the city centre became disused in 2018. However, it can be argued that Gaziantep Railway Station bears the potential to establish a strong relationship between railway networks and urban areas thanks to soon to be constructed high-speed railway lines.

\section{Gaziantep Railway Station: where Gaziantep railway meets the city}

Before the Gaziantap Railway Station was constructed, passengers would arrive at Narlı or Fevzipaşa Railway Station, which were nearly 54 kilometres away from the city centre. They then reached the city centre by bus or private cars (Figs. 6 and 7). In this period, people would usually travel to another city for military service, higher education, or to visit relatives. State officials would also arrive in Gaziantep by train. For example, Atatürk was welcomed at Narlı Railway Station on 21 January 1933 and taken to Gaziantep from there (Fig. 8). This event is still celebrated today.
Eating and drinking were also common daily practices on longer train journeys. People would usually bring their food on-board because there was no dining car. In his book, Alleben Stories, Ülkü Tamer, a prominent Turkish writer and poet, mentions how people would eat ice-cream in Ereğli, apples in Sapanca, and salep and simit in Eskişehir (Aydoğan, 2010). He also adds that he would disembark the train at Narlı Railway Station to approach Gaziantep by car, and take a break in Başpınar to eat kebab, saying "You could see Antep, the most beautiful painting in the world, as you were going beyond the hill", which would signal the end of a pleasant journey. The writer also states that people gave up the habit of taking a break at Başpınar to eat kebab and drink tea because a new railway station was built in Gaziantep. In the following year (1957), Eres Söylemez mentions how the train would proceed very slowly, and this allowed them to disembark the train and pick fruit in the nearby farming gardens. He also adds that many travellers would bring their food in straw baskets for 


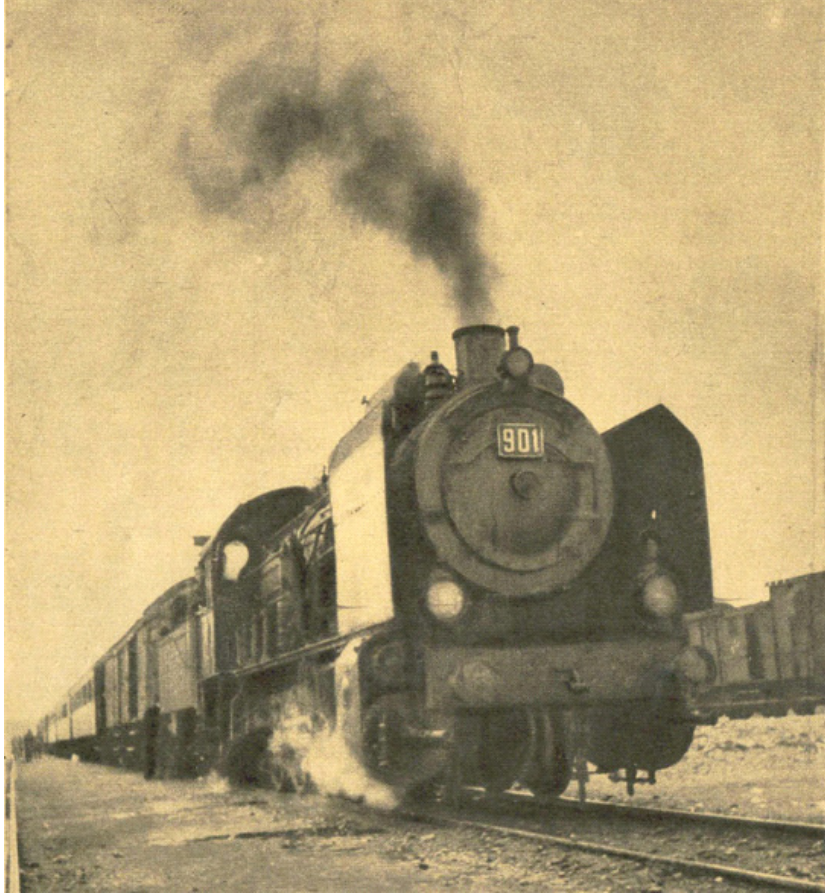

Fig. 6 Taurus Express, which runs between Haydarpasa-Baghdat route of $1600 \mathrm{~km}$. and 180 passenger capacity [Demiryolları Ulaşımı (Railway Transportation)].

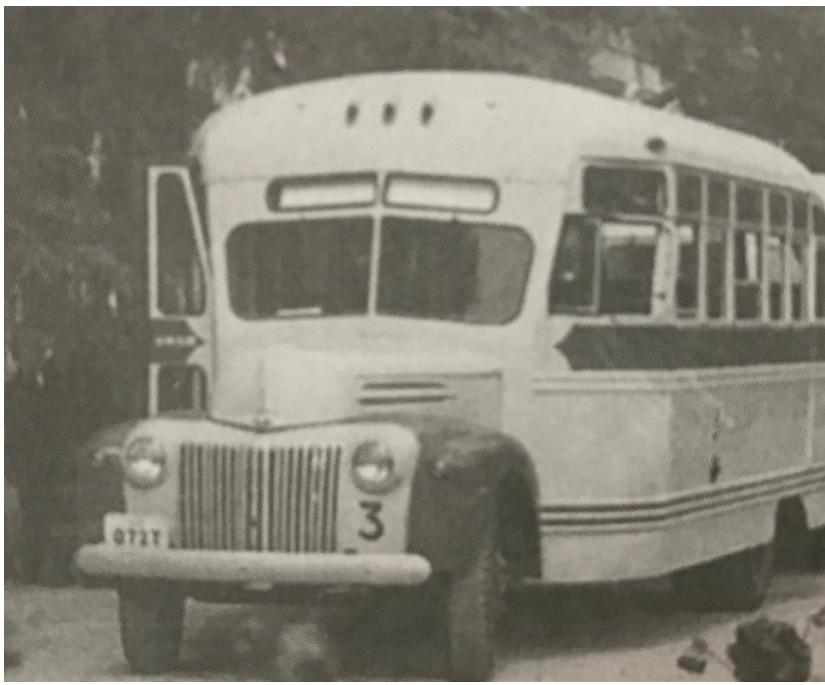

Fig. 7 The buses that runs between Narl1-Gaziantep dirt road which takes 5 hours, after the 3 day long train travel between İstanbul-Narl (Noyan, 2017).

long train journeys and would eat fenugreek sandwiches in Kayseri Yerköy (Söylemez, 2018).

The trains were then divided into three classes: first, second and third-class compartments (Fig. 9). The first class had red leather seats for four people, while the second class had green leather seats for six people. There were wooden seats in the third class. Because journeys were remarkably long due to the low-speed trains and adverse physical

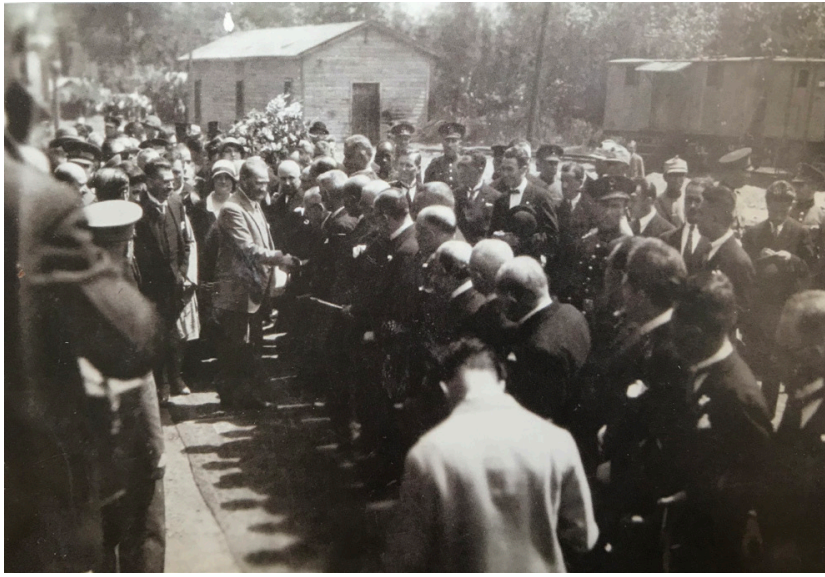

Fig. 8 Welcoming ceremony to Atatürk visiting Gaziantep, in the Narl1 train station, 26 January 1933 [Akcan Barlas Archive, (Köylüoğlu, 2009)].

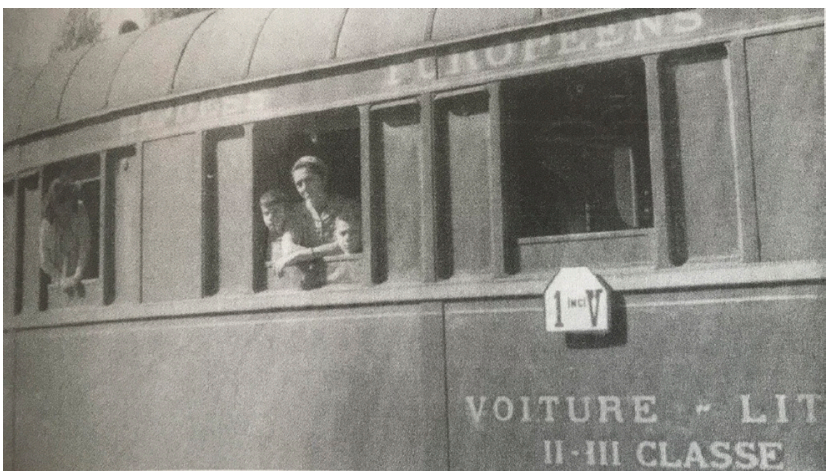

Fig. 9 Second and third class train cars in Gaziantep Train Station (Noyan, 2017).

conditions, some passengers would continue their journeys carrying wooden luggage on foot because there was a considerable crowd on-board. They would also sometimes compete with other passengers to find an empty seat. In addition, Ömer Kutlar narrates how they would close the windows on board to prevent mosquitos from entering the compartments and avoid the risk of contracting malaria while the train was passing through Gölbaşı after they embarked at Narlı (Maraş) or Fevzipaşa Railway Station (Kutlar, 2018). Similarly, Dr M. Akif Güleç states that a steam train called "Black Train" occupied an important place in their childhood memories and adds that they would stick their heads out of the windows while the train was passing through a tunnel, and smudge stains on their faces would not be easily cleaned once they arrived home (Güleç, 2018).

Like Gaziantep, railway stations were usually situated on a central axis defined as Railway Station Avenue, and this set the first example of modern geometric discipline in Anatolian cities and urban planning projects (Tanyeli, 1998). Aritan highlights that railway station avenues are connected to the main square along a line of 
avenue-square-public buildings to rationalize new urban life and provide citizens with common areas where they can easily socialize (Aritan, 2008). When compared to its current condition, Railway Station Avenue still functions as a key axis in the city centre with its important public buildings, sports areas and splendid trees (Figs. 10 and 11).

It was understood in these interviews that only one train arrived at the railway station when it was first built, and many people would come to the station to welcome it or send it off (Fig. 12). Train arrivals were significant events and a form of entertainment for the citizens, and many people would picnic near the railway station. It is still common to see barbecue smoke coming from Dülük forest on Sundays, which makes many people mistakenly think that there is a forest fire. Aydoğan and Tamer also mention in their books that train arrival at Antep was considered as an important event in the city (Aydoğan, 2010). According to Tamer, Antep citizens moved their main picnic location from Alleben Creek (Kavaklık) to the vicinity of the railway station square when it was first built.
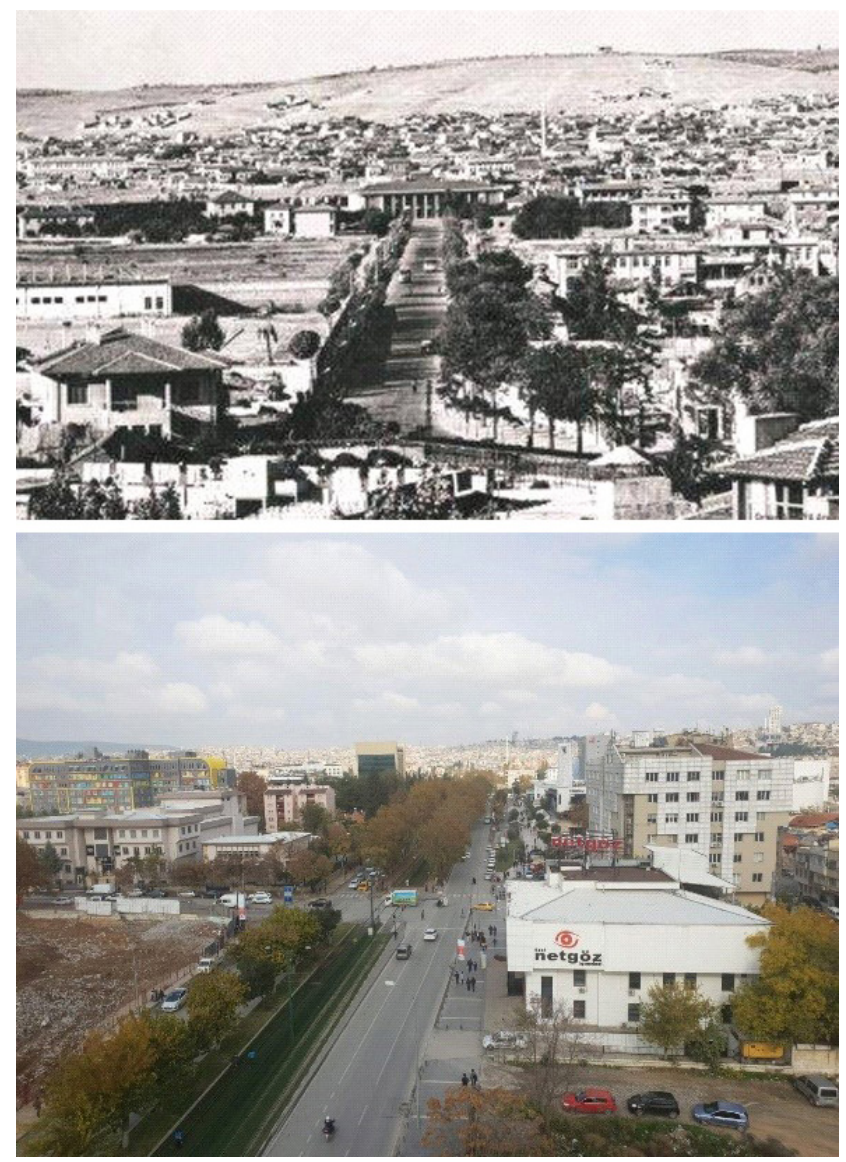

Fig. 10 (up) Old picture of Gaziantep Train Station in the city silhouette (WOW Turkey) (down) Today picture of Gaziantep Train Station from the Station Street looking north, 2018 (Güleç, 2018).

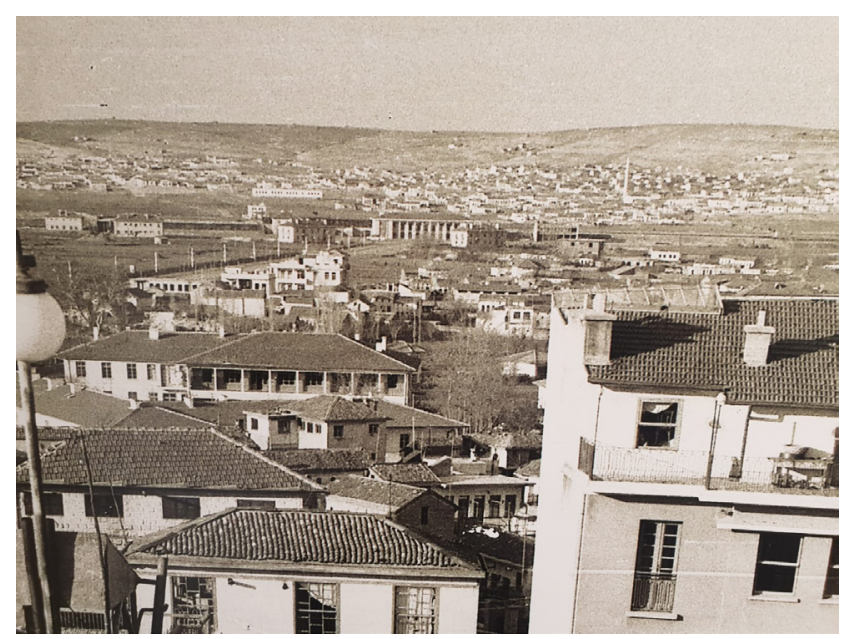

Fig. 11 Old picture of Gaziantep Station Building in the city silhouette looking from south (Biçer, 1960s).

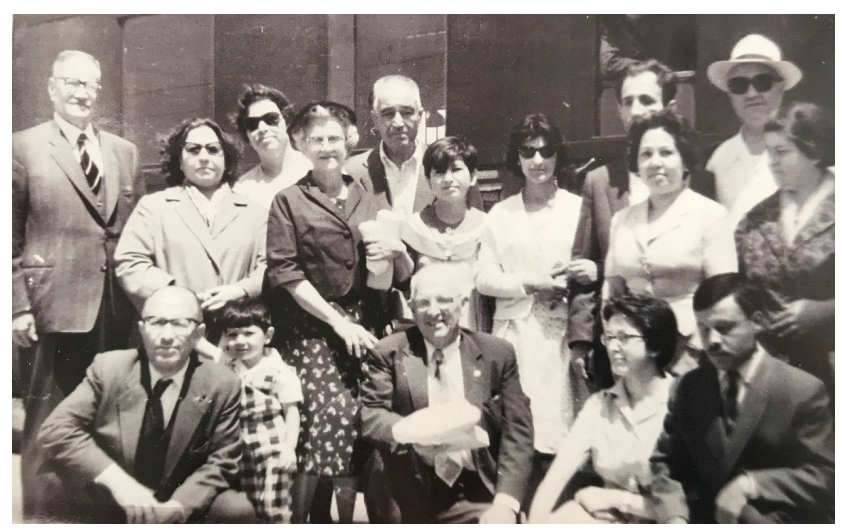

Fig. 12 Sendoff photograph of Mr. Aizli and his family from Gaziantep Train Station, who played an important role in afforestation of Dülük forest, 1961 [Prof. Dr. Ayşegül Ataman Archive from (Köylüoğlu, 2009)].

They would also swing between train cars and have barbecues (Tamer, 2008). However, the railway station lost its popularity in the following years.

The railway station (Fig. 13), which was built in 1951, after the railway system was introduced to Gaziantep, played an essential role in urban planning due to its spatial qualities. The square and avenue, formed following the construction of the railway station, provided Gaziantep with urban areas associated with railway structures.

Sukran Gögüşs stated that she was a high school student and took part in a stage play that was played at the opening ceremony of Gaziantep Narlı Railway and attended by then Prime Minister Adnan Menderes on 27 October 1953 (Fig. 14); she added that Muammer Bozok was the contractor of the railway station (Gögüss, 2018). Meanwhile, Turgay Noyan clearly states in his book that Şahap Sicimoğlu, who was then a well-known young civil engineer and contractor, purchased the state bid 


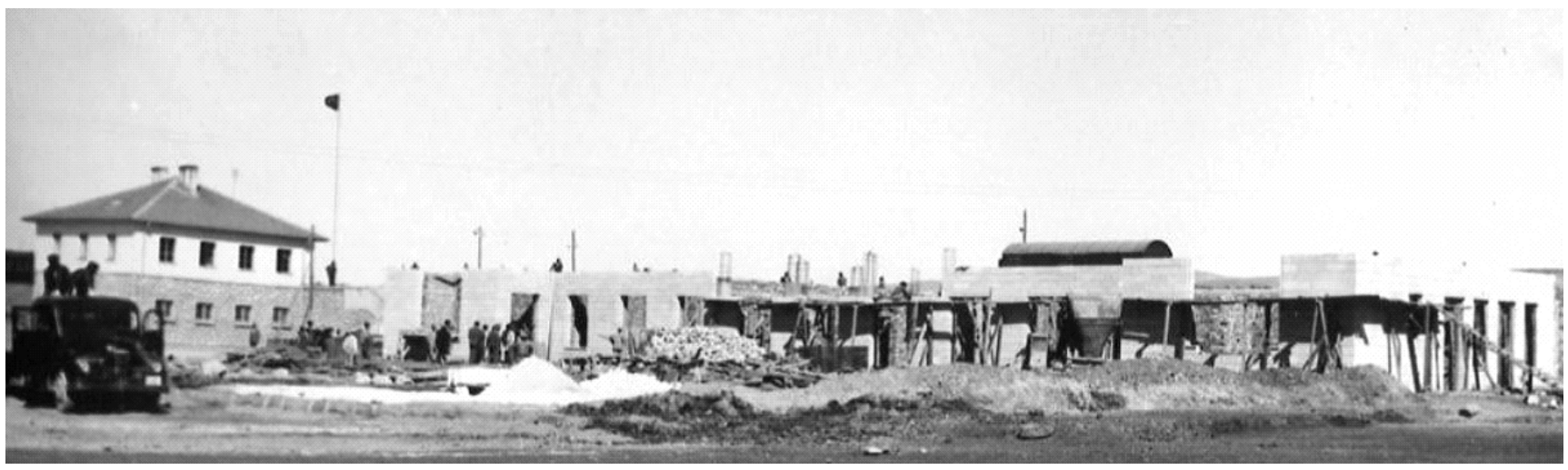

Fig. 13 A view from Gaziantep Train Station worksite- 1950s (Severoğlu, 2018).

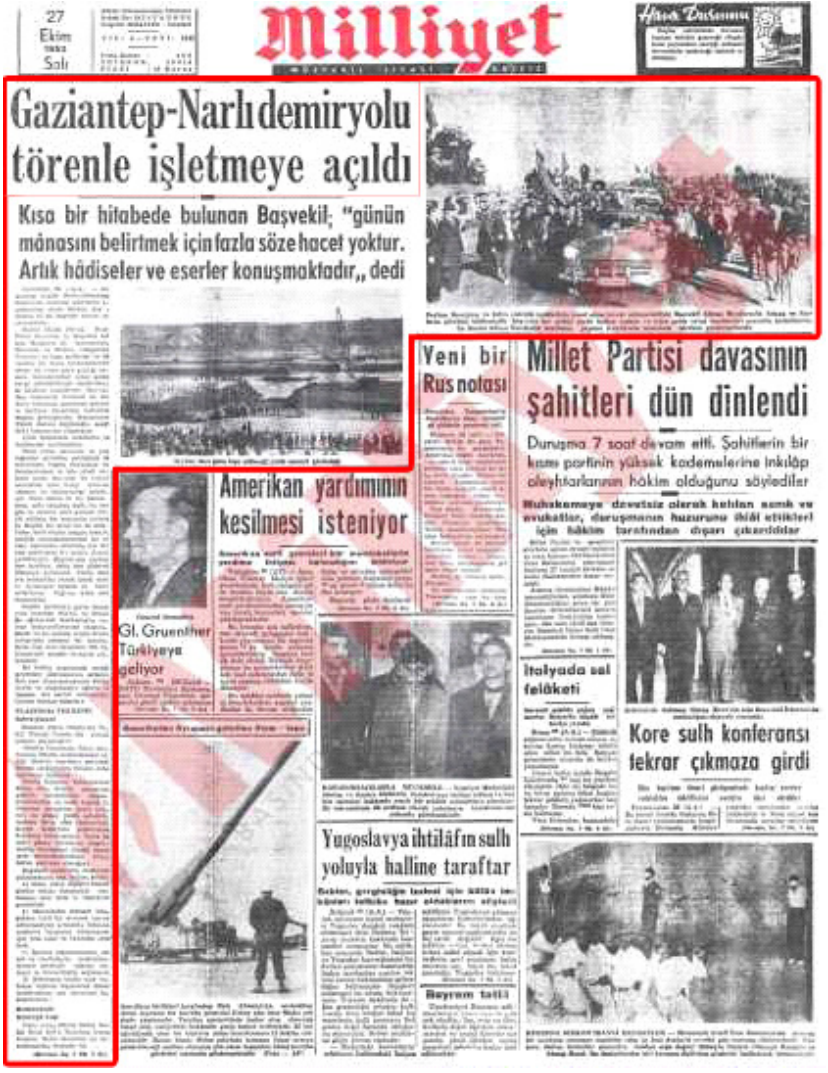

Fig. 14 Milliyet newspaper headlines "Gaziantep-Narlı Railway has opened with ceremony", 27 October 1953 (Milliyet Newspaper Archive).

and completed the construction of the railway station (Noyan, 2017). Although the principal architect of the structure is not definitely known, it can be stated that both Bozok and Sicimoğlu contributed to the Gaziantep Railway Station.

The importance of railways as a transportation system can be understood from the Prime Minister's participation in the opening ceremony. Dr Talat Göğüş states that Gaziantep Railway Station opened in 1953 and was named Toros Express, and it took 23 and 36 hours to arrive in Ankara and İstanbul by train, respectively (Göğüş, 2018). The reason why Gaziantep railway was named Toros Express may be considered as a reference to the success in building a railway network over a demanding mountainous area.

Many of the railway structures built in the early-republican era bear the traces of the First National Architecture Movement. The effects of modern architecture started to fade in the 1940s, and the Second National Architecture Structure started to significantly influence architectural designs. In this period, railways were considered as a vital tool to reflect Republican ideology, and new units were designed and implemented. A new architectural approach was adopted in railway building construction; horizontal and vertical spatial construction elements were used in monumental symmetrical planning and façade design. In this respect, it can be argued that these monumental façade elements of Gaziantep Railway Station (Erkan and Haştemoğlu, 2013) were designed in parallel with the Second National Architectural Movement (Fig. 15).

Gaziantep Railway Station was built in a modern and plain manner because the introduction of the railway system was relatively late. Despite its importance and meaning for the city, its colonnade entrances represent a structurally assertive building despite its modestly scaled structure. The stone used as a construction material is another assertive feature of the railway station. Stone is a

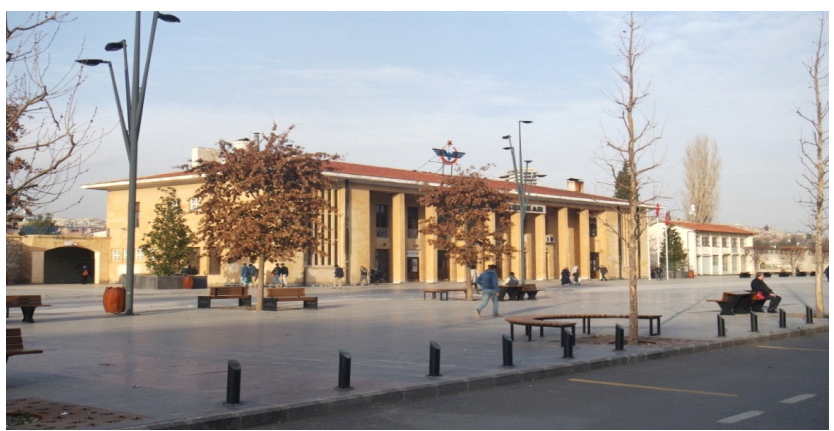

Fig. 15 Gaziantep Train Station, 2017 (Güleç, 2017). 
sustainable building element (Yardımlı et al., 2018; Yardimlı et. al., 2020). In the Middle East, havara stone (soft limestone), topak stone, keymih (hard limestone), minaret rock, basalt (sphalerite), white marble, red marble and some colourful stones are most used in construction. In the railway station structure, keymih stone was preferred on the external façade due to its hard structure, whereas havara stone was used indoors due to its soft and easily carvable nature. This choice can also be associated with a proverb in Gaziantep, where the havara stone that was used for railway station construction, is compared to a rich person:

"Fukara adam keymıh taşı, değersin yaralar; zengin adam havara taşı, değersin tozu bulaşı."

(Keymih stone is a poor man, hurts when you touch; havara stone is a rich man, dusts when you touch.)

Gaziantep Proverb

The railway station building consists of a basement, ground floor, and a first floor. It has a glass ceiling, which can be considered as an advanced architectural technique for this period (Noyan, 2017). A passenger lounge and ticket offices can be found at the entrance of the ground floor, which is also called a hall. The two-storey hall (which is 8 meters high) includes waiting lounges, kitchen, cold storage room, restrooms and other storage areas, a baggage claim office, post office, and an administrative unit. On the upper floor is a two-storey hall that includes administrative staff offices, a telegraph office and other bureaus, which can be found on one side, while post office and police offices, a restaurant, its entrance and restroom are on the other side. Two staircases can be found on the eastern and western sides of the building. It is possible to reach the basement by going down the stairs on the eastern side where a boiler room, ash removal room, coal cellar, workers' room, and storage and restrooms can be found. While the staircase on the eastern side only connects the ground and first floors, the staircase on the eastern side connects all the floors. There is an elevation difference of 3.80 meters between the ground and first floor, which is also used as a railway platform (Fig. 16).

Although the railway system was introduced to Gaziantep later compared to other Anatolian cities, it heavily influenced urban and daily life in the city. The spatial effect of the railway station in the 1950s can be understood from the celebration of Atatürk's arrival at Narlı Railway Station and visit to Gaziantep. From a
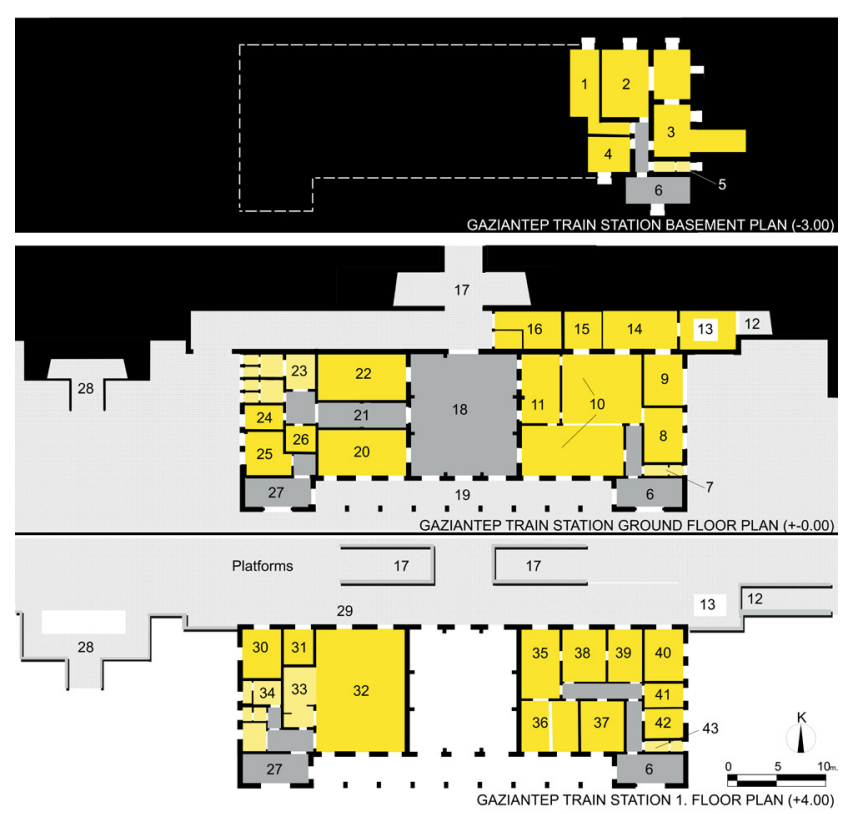

Fig. 16 Gaziantep Train Station Floor Plans: 1. Technical Room,

2. Tank, 3. Boiler Room, 4. Technical Room, 5. WC, 6. Staircase,

7. WC, 8. Room, 9. Room, 10. Luggage Room, 11. Ticket Counter,

12. Staircase to platforms, 13. Elevator, 14-16. Room, 17. Staircase to platforms, 18. Passenger Lounge, 19. Main Entrance, 20. Room,

21. Corridor, 22. Room, 23. WC, 24. Room, 25. Kitchen,

26. Depot, 27. Staircase, 28. Staircase to platforms, 29. Staircase to platforms, 30-31. Room, 32. Dining Hall, 33. Kitchen, 34. WC, 35-42. Room, 43. WC.

technical point of view, the materials used in the basement (havara stone) indicates that the state officials attached importance to the building. Although Gaziantep Railway Station influences the city from a spatial perspective, it does not seem to integrate into the spatial policies in other Anatolian cities in the early-Republican era.

When looking through the city today, Gaziantep Station has been restored and closed for several years. Nevertheless, the train station is still at the heart of the city thanks to its location at the intersection points of Zafer and İstasyon (Station) Streets. A new high-speed railway and station are planned to be opened soon (Fig. 17).

\section{Conclusion}

Railway systems were first introduced to the world following the Industrial Revolution in the UK when they were used as a transport network to transfer raw materials. Thus, steamships and engines became widespread around the globe.

The introduction of railways to Turkey coincided with the late-Ottoman period when the first railway line between Aydin and Constanta was built in the early nineteenth century. This line later reached some Anatolian cities and transformed them spatially, which eventually contributed to 


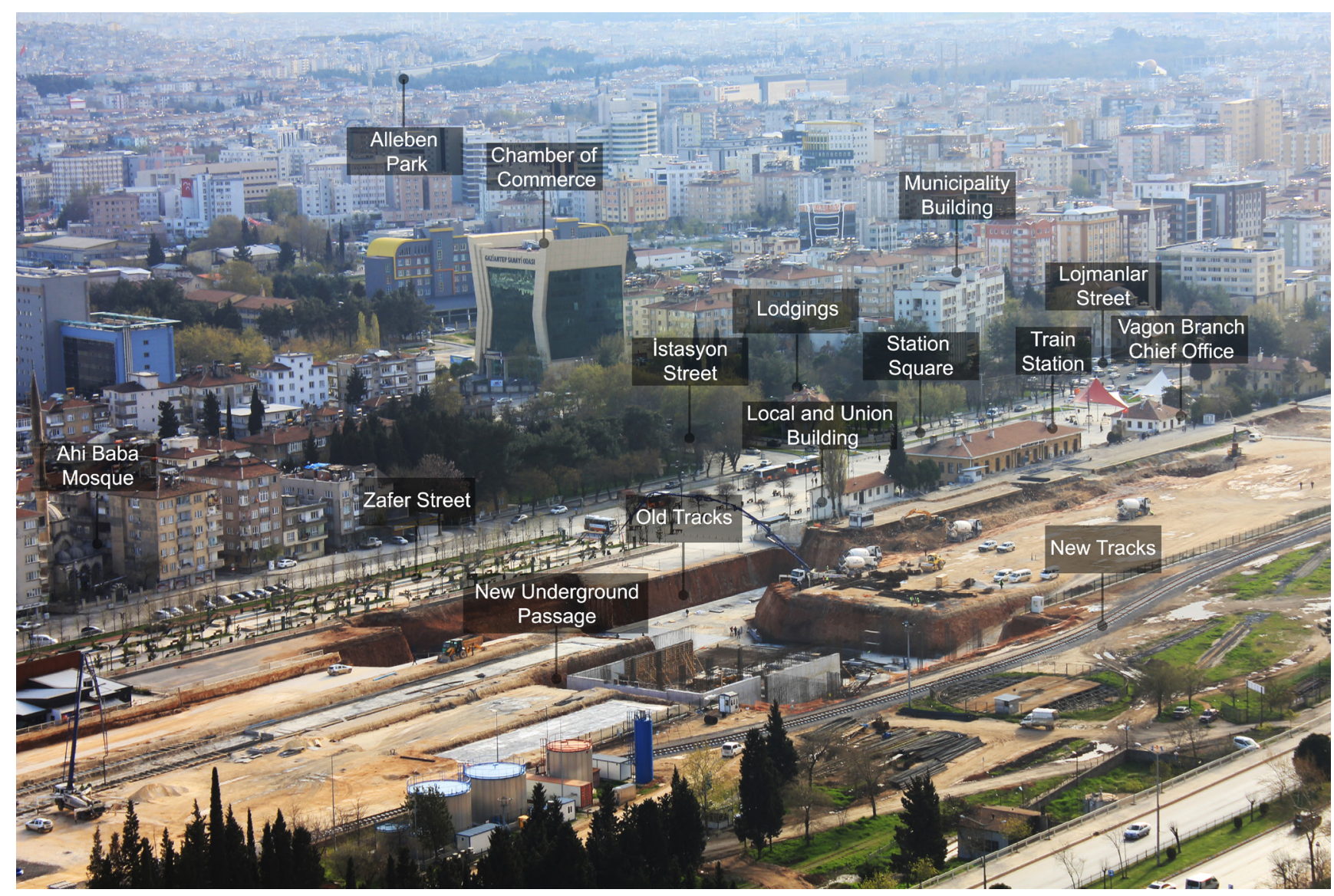

Fig. 17 General View of Gaziantep, showing today's situation of the station and its connection to the city, 2019.

British colonization. The last attempt was made in the late nineteenth century, before the Republican era, and a railway line and station were built in Ankara in 1892.

Following the proclamation of the Republic, the railway network, designed as a transportation system in Anatolia, reached Gaziantep in 1927. However, it was only in 1951 when the first railway system was built in Gaziantep. The lack of a railway system in Gaziantep, which was planned simultaneously with other Anatolian cities, can only be attributed to the city being surrounded by a mountainous area.

Although the city is located on the old Silk Road, a railway station was built in Gaziantep nearly half a century later than the railway was introduced to Anatolia. In this respect, the relatively late introduction of railway systems to Gaziantep is related to its secondary position as a colonialization centre for European powers rather than its role as a commercial centre creating a bridge between Anatolian and Central Asian countries.

That Gaziantep Railway Line was called Toros Express is a reference to the mountainous geography of the region and its impact on the railway system. Although Herman Jansen designed a railway station as a crucial part of urban planning in Gaziantep, the introduction of railways to the city 13 years later than expected caused many problems in terms of defence during World War II. Thus, a railway system, which was a component of Jansen Plan, was only built in the city in 1951. The railway station was built following the design in the Jansen Plan. Consequently, the late introduction of the railway system to Gaziantep, compared to other Anatolian cities restricted its transportation network. Nevertheless, Gaziantep Railway Station has occupied an influential position in the daily urban and social life of Gaziantep.

\section{Acknowledgement}

We would like to thank TCDD 6. Regional Directorate (Adana), Gaziantep Metropolitan Municipality Planning Department, Natura Architecture Design and Restoration Firm, Ali İhsan Dağyar and Sitkı Severoğlu for their contributions. 


\section{References}

Aycı, H., Akbulut, S. (2018) "Jansen'in Ankara Planı'nda Demiryolu'nun Etkileri" (Effects of Railway in Jansen's Ankara Plan), In: International Jansen ve Ankara Symposium, Ankara, Turkey. (in Turkish)

Aydın, S. (2012) "Umram Yolu, Demiryollarının Gelişimi ve Türkiye Demiryolları" (Umram Road, Development of Railways and Turkish Railways), İletişim Publications, Istanbul, Turkey, pp. 11-118. (in Turkish)

Aydoğan, B. (2010) "Ülkü Tamer'in Alleben Anıları ile Alleben Öyküleri'ndeki Antep" (Alleben Memories of Ülkü Tamer and Antep in Alleben Stories), Journal of Cukurova University Social Sciences Institude, 19(3), pp. 183-196. (in Turkish)

Arıtan, Ö. (2008) "Modernleşme ve Cumhuriyetin Kamusal Mekân Modelleri" (Modernization and Public Space Models of the Republic), Mimarlik, 342, Article Number: 51. (in Turkish)

Beyhan, B., Uğuz, S. (2012) "Planning as a Tool for Modernization in Turkey: The Case of Hermann Jansen's Plan for Mersin (1)", METU JFA, 29(2), pp. 1-34. https://doi.org/10.4305/METU.JFA.2012.2.1

Biçer, H. Z. (1960) "Old picture of Gaziantep Station Building in the city silhouette looking from south", [photograph] Private collection, Gaziantep, Turkey.

Çavdar, S. (2018) "Herman Jansen Gaziantep Planı" (Gaziantep Plan of Herman Jansen), In: International Jansen and Ankara Symposium, Ankara, Turkey. (in Turkish)

Cephanecigil, G. (2018) "Gaziantep Planı: Süreç Üzerine Değerlendirmeler (Gaziantep Plan: Evaluations on the Process)", In: International Jansen and Ankara Symposium, Ankara, Turkey. (in Turkish)

Day, L., McNeil, I. (1966) "Biographical dictionary of the history of technology", Routledge, London, UK.

Demiryolları Ulaşımı (Railway Transportation) "Toros Ekspresi - Tarihi Bir Tur" (Toros Express - A Historical Tour), [online] Available at: https://demiryollariulasimi.page.tl/Toros-Express.htm [Accessed: 11 February 2019] (in Turkish)

Erkan, I., Haştemoğlu, H. S. (2013) "Cumhuriyet Dönemi Mimarlığı: Anadolu'da Modern Bir İstasyon Binası, Ali Çetinkaya İstasyonu" (Republican Period Architecture of the Rebuplican Period: A Modern Station Building in Anatolia, Ali Çetinkaya Station), Mimarlik, 374, Article Number: 16. (in Turkish)

Gülsoy, U. (1994) "Hicaz Demiryolu" (Hicaz Railway), PhD Thesis, Marmara University, Institute of Turkish Research. (in Turkish)

Güleç A. (2017) "Gaziantep Train Station", [photograph] Private collection, Gaziantep, Turkey.

Güleç A. (2018) "Today picture of Gaziantep Train Station from the Station Street looking north", [photograph] Private collection, Gaziantep, Turkey.

Güleç, M. A (2018) "Childhood in Gaziantep", [conversation] (Personal communication, 26 October 2018).

Göğüş, Ş (2018) "Once upon a time in Gaziantep", [phone call] (Personal communication, 21 October 2018).

Göğüş, T. (2018) "Gaziantep memories", [phone call] (Personal communication, 19 October 2018).

Işıksaçan, M. (1961) "Türkiye Demiryollarında Tarihi Olaylar" (Historical Events in Turkish Railways), Journal of Demiryol, pp. 434-435. (in Turkish)
Jansen, H. (1938) "Gaziantep Planning Report", [printed] 23414, Berlin: TU Berlin Architecture Museum.

Keskinok, H. Ç. (2010) "Urban Planning Experience of Turkey in the 1930s", METU JFA, 27(2), pp. 173-188. https://doi.org/10.4305/METU.JFA.2010.2.9

Keskinok, Ç. (2018) "Railway", [conversation] (Personal communication, 19 October 2018).

Koyluoglu, A. (2009) "Kadim Şehir Gaziantep" (Ancient City Gaziantep), Gaziantep, Turkey. (in Turkish)

Kopar, M. (2011) "CHP Teftiş Raporlarına Göre II. Dünya Savaşı Y1llarında Gaziantep" (According to CHP Inspection Reports, Gaziantep in II. World War Years), Gaziantep University Journal Of Social Sciences, 10(3), pp. 1037-1055. (in Turkish)

Kutlar, Ö (2018) "Memories about the Gaziantep Railway Station", [conversation] (Personal communication, 21 October 2018).

Milliyet "Milliyet Newspaper Archive, 27th October 1953", [online] Available at: http://gazetearsivi.milliyet.com.tr/Arsiv/1953/10/27 [Accessed: 11 February 2019] (in Turkish)

Noyan, T. (2017) "Kayacık Hikayeleri: Gaziantep'in Tayyareli Yılları" (Stories of Kayac1k: Airplane Years in Gaziantep), Naviga Publishing, Kadıköy, Istanbul, Turkey. (in Turkish)

Severoğlu, S. (2018) "A view from Gaziantep Train Station worksite", [photograph] Private collection, Gaziantep, Turkey.

Slotterback, C. S. (2010) "Public Involvement in Transportation Project Planning and Design", Journal of Architectural and Planning Research, 27(2), pp. 144-162.

Sönmez, F., Selçuk, S.A. (2018) "Kayseri Tren İstasyonu ve Çevresinin Kentin Modernleşme Sürecine Katkısı Üzerine Bir Okuma" (A Reading on the Contribution of Kayseri Train Station and its Environment to the Modernization Process of the City), Megaron, 13(1), pp. 85-101.

Söylemez, E (2018) "Memories about the past", [conversation] (Personal communication, 21 October 2018).

Tamer, Ü. (2008) "Alleben Öyküleri" (Alleben Stories), Kırmızı Yayınları, Istanbul, Turkey. (in Turkish)

Tanyeli, U. (1998) "Mekanlar, Projeler, Anlamları" (Spaces, Projects, Meanings), In: Tanyeli (ed.) Üç Kuşak Cumhuriyet (3 Generations of Republic), Turkish History Foundation Publications, Istanbul, Turkey, pp. 101-107.

Tekeli, İ., İlkin, S. (2001) "Cumhuriyetin Demiryolu Politikalarının Oluşumu ve Uygulaması" (Formation and Application of the Republic's Railway Policies), Kebikeç, 11, pp. 125-164. (in Turkish)

Yardımlı, S, Shahriary, A, Özer, D. G. (2018) "Sürdürülebilir Yapı Örneği Olarak Yazd'da Konut Analizi" (Housing Analysis in Yazd as a Sustainable Building Example), Online Journal of Art and Design, 7(2), pp. 39-53. (in Turkish)

Yardımlı, S, Özer, D. G., Shahriary, A (2020) "Sustainable Street Architecture and its Effects on Human Comfort Conditions: Yazd, Iran", A|Z ITU Journal of the Faculty of Architecture, 17(2), pp. 113-122.

https://doi.org/10.5505/itujfa.2020.70188 
Yenice, M. S., Yenice, T. K. (2018) "Gaziantep Kenti Planlama Deneyimleri Üzerine Bir Süreç Değerlendirmesi" (A Process Assessment on Gaziantep City Planning Experiences), Gaziantep University Journal Of Social Sciences, 17(2), pp. 552-562. (in Turkish)

https://doi.org/10.21547/jss.374644
WOW Turkey "Gaziantep'te Nostaljik Gezinti: Eski Fotoğraflar" (Nostalgic Tour in Gaziantep: Old Photographs), [online] Available at: http://wowturkey.com/forum/viewtopic.php?t=24485\&start=330 [Accessed: 11 February 2019] (in Turkish) 